\title{
Impact of Selenium on Structural Changes Induced by Hypothyroidism In Adult Male Rat's Testis
}

\author{
Eman G. Alhealy ${ }^{1}$, Maysoon M. Alqazzaz ${ }^{2}$, Wahda M. AL-Nuaimy ${ }^{3}$ \\ 1 Department of Anatomy, College of Medicine, University of Ninevah, Mosul, Iraq. 2 Department of \\ Anatomy, College of Medicine, University of Mosul, Mosul, Iraq. \\ 3 Department of Pathology, College of Medicine, University of Mosul, Mosul, Iraq. \\ Corresponding author: Eemanalhealy6@gmail .com
}

$\underline{\text { Received }} \quad \underline{\text { Accepted }}$

\begin{abstract}
Background: Hypothyroidism is a common thyroid disorder which influences the function of many organs including the reproductive organ

Aim of this work: To examine the structural changes induced in the testis of adult male rats by hypothyroidism and the possible protective role of selenium.

Methods: forty male albino rats were classified into 4 groups; Group I: used as a control. Group II: were given carbimazole for hypothyroid induction; and Group III, IV received selenium alone and combination of carbimazole with selenium respectively, orally for 3 months

Results: The all outcomes of Group I and Group III rats showed no significant difference; therefore, they were collective in one group (control). Serum concentration of TSH was significantly increase while the level of T4, and testosterone concentrations were significantly decreased in groups II and IV. Testis of hypothyroid rats showed irregularity of some seminiferous tubule with thickening of their basement membrane, the diameter of seminiferous tubule and the height of germinal epithelium significantly decreased with decreases in the number of spermatocytes, Sertoli and Leydig cells. There was disorganization of the germinal epithelium with vacuolar degeneration of spermatocyte. In Addition, there was a widening of interstitium associated with edema and congested blood vessels. However, rats of group IV showed significantly an improvement in hormonal level and histological structure of the testicular tissue compared to group II. Conclusion: hypothyroidism affects the structure of a testis but adding selenium has ameliorative role on thyroid function and histological changes of the testis.
\end{abstract}

Keywords: hypothyroidism, selenium, testis.

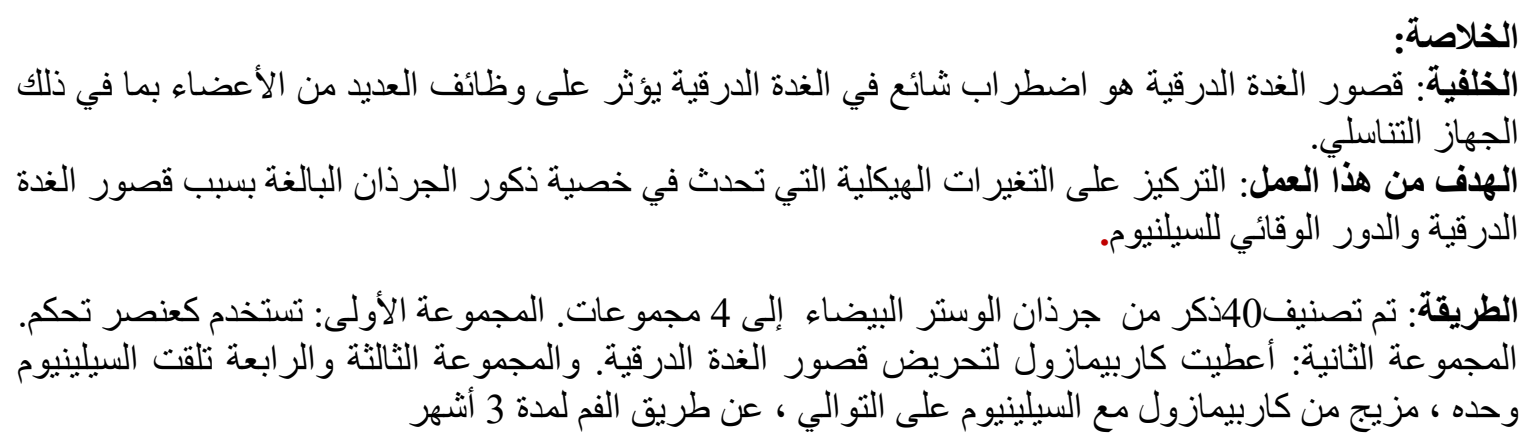




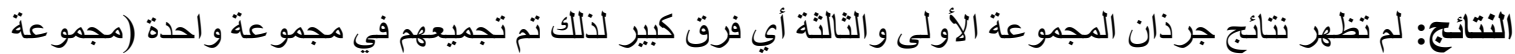

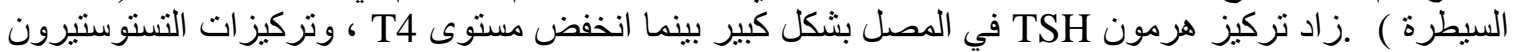

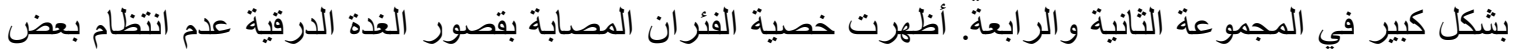

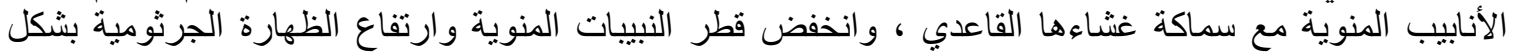

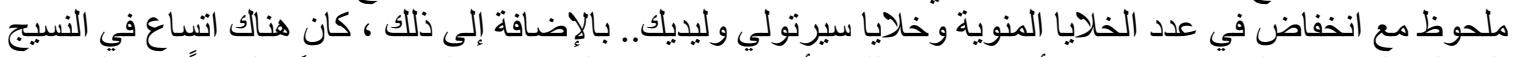

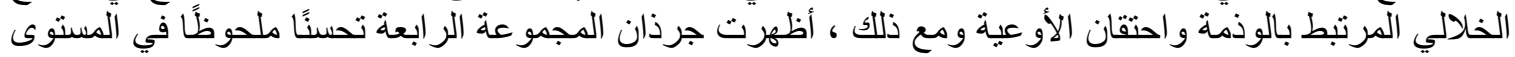

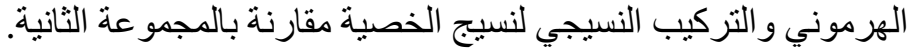

الخلاصة: قصور الغدة الدرقية يؤثر على بنية الخصية ولكن إضافة السيلينيوم له دور محسن في وظيفة الغدة الدرقية و التغيرات النسيجية للخصية والتي يمكن أن تعزى إلى نشاطها كمضاد للأكسدة.

$$
\text { الكلمات المفتاحية: قصور الغدة الدرقية ، السيلينيوم ، الخصية, الجرذان }
$$

\section{INTRODUCTION:}

$\mathrm{T}$ he thyroid gland secretes thyroxin (T4) and triiodothyroine (T3) hormones ${ }^{1}$. These hormones play a critical role in controlling the infant's brain and somatic ddevelopment and in the adult they regulate metabolic activity and the function of many organs ${ }^{2}$. Previously, the scientist was thought that male gonads were unresponsive to thyroid hormones; however, recently thyroid receptors have been discovered in various tissues of the body including the gonads ${ }^{3,4}$. Many investigators studied the relationship between the thyroid hormones and male reproductive system, the thyroid gland controls the proliferation and maturation of Sertoli cells and Ledyig cells during the developmental stage of testis in human and rodents ${ }^{4-6}$.

Thyroid dysfunction is a public problem, the incidence of thyroid disorder is increased considerably during the last decade ${ }^{7}$. Hypothyroidism is the most common thyroid dysfunction, the prevalence of which is correlated to age and $\operatorname{sex}^{8}$. Many organs in the body can be affected by thyroid dysfunction including male reproductive organ ${ }^{9}$. Hypothyroidism in post-pubertal men triggered many sexual dysfunctions as decreased libido and delayed ejaculation ${ }^{5}$. The researcher showed that male fertility was not affected in short term hypothyroidism while impairment of reproductive function had been reported in prolonged condition ${ }^{10}$. However, decreased thyroid hormones level in hypothyroidism influence the number of Sertoli cells and altered the shape and motility of the sperm leading to fertility impairment ${ }^{11}$.

Hypothyroidism is associated with the reduction of antioxidant defense mechanism against free radicles which produced by normal cellular metabolism $^{12,13}$. The accumulation of free radicles is responsible for abnormal function of the cells with increased cell death ${ }^{14}$.

Selenium (Se) is an essential micronutrient element for $\Gamma$ animals, it has an antioxidant properties ${ }^{15}$. And plays an important role in several physiological processes such as immunity and thyroid hormones production $^{16}$. It has been used widely as an anticancer in several conditions including liver and renal cancer ${ }^{17}$. It has a protective role against the cisplatininduced hepatotoxicity in mice ${ }^{18}$.

Therefore, the objective of this study was to ddetermine the impact of 
selenium on the histological changes in the testis of hypothyroid rats induced by carbimazole (antithyroid) drug.

\section{MATERIAL AND METHODS}

2.1.Carbimazole: is an antithyroid drug obtained from the local markets in Iraq as tablets supplied under the trade name NeoMercazole. It was dissolved in distilled water and orally administered to animals at a dose level of $6 \mathrm{mg} / \mathrm{kg}$ $\mathrm{BW}^{19}$.

2.2. Selenium: is an antioxidant agent existing as sodium selenite powder. It was dissolved in distilled water and огally administered to animals at a dose level of $10 \mu \mathrm{g} / \mathrm{kg} \mathrm{BW}^{20}$.

\subsection{Experimental protocol}

Forty adult male Wistar albino rats weighing about (190- 225) grams and aged about three months were purchased from the animal house of Veterinary College, University of Mosul. They were housed in polypropylene cages for period from the 1st of January till the 1st of April 2020. The animals were kept in well-ventilated cages, under standard environments, with free access to the standard diet and water. All animals had been examined carefully for general health status. The animals were ddivided into four $\mathrm{groups}$ (ten rats in each group) as following: Group I (control group) receive 0.5 distilled water daily for three months. Group II (hypothyroid group) the animals in this group received carbimazole dissolvent in water and given as $0.5 \mathrm{ml}$ orally by gastric tube once daily for three months to induce hypothyroidism. Group III ( $\mathrm{Se}$ treated) rats were given distilled water daily for three months and selenium was added orally by gastric tube once daily for the last two months. Group IV (hypothyroid + Se) rats were given carbimazole as same as group II but we added sodium selenite orally by gastric tube once daily for the last two months. Towards the end of the experiment blood samples were collected from the retго-огbital venous plexuses for serum separation. Then all animals were killed by cervical decapitation, the testes were dissected out, the right testis used to estimate the level of Malonaldehyde (MDA) which regard as marker for oxidative stress while the left testis was fixed in Bouin's solution and processed through a series of alcohol dilutions and embedded in the paraffin wax to get sections of $5 \mu \mathrm{m}$ thickness which stained with haematoxylin-eosin $(H \& E)$ to be examined under the light microscope.

2.3.1. Hormonal assay: All blood samples were aspirated in the morning about 10-11 AM. The blood centrifuged at $400 \mathrm{r}$ Pm for 15 mint then serum was separated and stored at $-20^{\circ} \mathrm{C}$. Serum TSH, T4 and sex hormones (testosterone) were determined by using the minividis technique.

2.3.2. Morphometrical analysis: using color $\Gamma$ USB digital Image camera, which was provided with image processing software for $\Gamma$ measuring all parameter. Seminiferous tubule diameter, germinal epithelium thickness were measured in six sections perr testis from ten ddifferent rats in each group at magnification power $400 \mathrm{X}$. Also, numbers of different germinal cells, Sertoli cells, and Leydig cells were also countedd in the same slides.

2.4. Statistical analysis : All data were reported as mean $\pm \mathrm{SE}$ (standard error $)$ ). Statistical significant of data was performed by Graph pad prism using one-way ANOVA followed by the 
Student-Newman-Keuls multiple comparison tests with the level of significance set at $\mathrm{P} \leq 0.05$.

\section{RESULTS}

The all outcomes of Group I (control) and Group III (selenium treated) rats showed no significant difference; therefore, these two groups were collective in one group (control).

\subsection{Hormonal}

Analysis:

Hypothyroidism was established by measuring TSH and T4. The serum concentration of TSH ,T4 level and testosterone were offered in Table (1) and Table(2). Serum TSH was significantly increased at $(\mathrm{p} \leq 0.05)$ while T4 was significantly decreased in GII (hypothyroid) followed by GIV (hypothyroid $+\mathrm{Se}$ ) in comparison to control group and there was a significant difference between both treated groups (GII and GIV. The serum concentration of testosterone showed the least significant decrease in GII followed by GIV compared to control group. There was a significant differences between both treated groups.

\subsection{Oxidative stress biomarker of the testis: The mean concentration of MDA in the testis was highest significant in Group II (hypothyroid)}

followed by Group IV (hypothyroid + Se) in comparison to control group. The MDA level in Group IV was decreased but the difference was not significant compared to group II $(\mathrm{P}>0.05)$ (Table $3)$.

\subsection{Quantitative-micro-morphometrical measurement:}

A- parameters of seminiferous tubule (ST) were illustrated in the table (4): there was a significant decrease in diameters of ST of hypothyroid group at ( $\mathrm{P} \leq 0.05)$ compared to control and hypothyroid + selenium treated groups. In addition, the height of germinal epithelium reduced in treated groups with significant decrease in hypothyroid group at $(\mathrm{P} \leq 0.05)$ compared to control group but the difference was not significant compared to hypothyroid+ selenium treated group. Whereas the thickness of basement membrane of ST was significantly increased in hypothyroid group compared to both control and hypothyroid +selenium treated groups. P-values of spermatogenic, Sertoli, and Leydig cells were presented in table(5). Hypothyroidism caused a statically significant reduction in a number of spermatogenic, sertoli and leydig cells $(\mathrm{P} \leq 0.05)$ 
Table 1: serum concentration of thyroid hormones in different groups of male rats .Data were expressed as Mean $\pm \mathrm{SE}$

\begin{tabular}{|c|c|c|c|}
\hline Groups & GI (Control) & GII (Hypothyroid) & GIV(Hypothyroid+Se) \\
\hline Parameters & & & \\
\hline TSH $(\mu \mathrm{lU} / \mathrm{ml})$ & $2.68 \pm 190 \mathrm{~A}$ & $5.86 \pm 0.03 \mathrm{~B}$ & $4.42 \pm 0.11 \mathrm{C}$ \\
\hline T4 $(\mathrm{nmol} / \mathrm{L})$ & $76.66 \pm 1.49 \mathrm{a}$ & $55.67 \pm 0.18 \mathrm{~b}$ & $67.47 \pm 1.16 \mathrm{c}$ \\
\hline
\end{tabular}

-Different letters mean there is a significant difference at $\mathrm{p} \leq 0.05$.

Table 2: The serum concentration of testosterone in different groups of male rats . Data were expressed as Mean $\pm \mathrm{SE}$

\begin{tabular}{|l|c|c|c|}
\hline Parameter & Control group & Hypothyroid group & Hypothyroid+Sel group \\
\hline $\begin{array}{l}\text { testosteroe } \\
\text { (ng/ml) }\end{array}$ & $4.39 \pm 0.37 \mathrm{~A}$ & $0.68 \pm 0.10 \mathrm{~B}$ & $2.34 \pm 0.17 \mathrm{C}$ \\
\hline
\end{tabular}

-Different letters mean there is a significant difference at $\mathrm{p} \leq 0.05$.

Table 3: The effect of hypothyroidism on MDA level in testicular tissues.

\begin{tabular}{|c|c|c|c|}
\hline \multirow[b]{2}{*}{ Parameters } & \multicolumn{3}{|c|}{ Groups } \\
\hline & Control group & Hypothyroid group & Hypothyroid+Se group \\
\hline $\begin{array}{c}\text { MDA } \eta g / g r a m \\
\text { tissue }\end{array}$ & $212.10 \pm 8.73 A$ & $350 \pm 10.26 \mathrm{~B}$ & $315.8 \pm 6.38 \mathrm{C}$ \\
\hline
\end{tabular}

-Different letters mean there is a significant difference at $\mathrm{p} \leq 0.05$.

Table (4): The parameters of ST $(\mu \mathrm{m})$.

\begin{tabular}{|l|c|c|c|}
\hline \multicolumn{1}{|c|}{ Groups } & $\begin{array}{c}\text { Tubular } \\
\text { diameter }\end{array}$ & $\begin{array}{c}\text { Germinal } \\
\text { epithelium } \\
\text { thickness }\end{array}$ & $\begin{array}{c}\text { Basement } \\
\text { membrane } \\
\text { thickness }\end{array}$ \\
\hline GI (Control) & $373.6 \pm 50.9 \mathrm{a}$ & $91.5 \pm 5.03 \mathrm{~A}$ & $2.0 \pm 0.1 \mathrm{a}$ \\
\hline GII (Hypothyroid) & $172.7 \pm 20.9 \mathrm{~b}$ & $70.06 \pm 5.2 \mathrm{~B}$ & $2.9 \pm 0.3 \mathrm{~b}$ \\
\hline GII(Hypothyroid+Se) & $338.6 \pm 28.2 \mathrm{a}$ & $77.2 \pm 3.2 \mathrm{AB}$ & $1.4 \pm 0.1 \mathrm{a}$ \\
\hline
\end{tabular}

-Different letters with in column mean there is a significant difference at $\mathrm{p} \leq 0.05$. -similar letters within column mean there is a non-significant difference at $p>0.05$. 
Table (5): The values of spermatogenic, sertoli and leydig cells.

\begin{tabular}{|c|l|l|l|l|l|}
\hline Groups & speratogonia & spermatocyte & spermatid & sertoli & leydig \\
\hline $\begin{array}{c}\text { GI } \\
\text { (Control) }\end{array}$ & $61.5 \pm 1.0 \mathrm{a}$ & $174.2 \pm 3.8 \mathrm{~A}$ & $215.7 \pm 3.8 \mathrm{a}$ & $19.5 \pm 0.8 \mathrm{a}$ & $\begin{array}{l}29.3 \pm 0.9 \\
\mathrm{a}\end{array}$ \\
$\begin{array}{c}\text { GII } \\
\text { (Hypothyroid) }\end{array}$ & $52.2 \pm 3.0 \mathrm{ab}$ & $56.2 \pm 1.6 \mathrm{~B}$ & $96.2 \pm 4.2 \mathrm{~b}$ & $7.8 \pm 0.5 \mathrm{bc}$ & $\begin{array}{l}5.2 \pm 0.5 \\
\mathrm{~b}\end{array}$ \\
\hline $\begin{array}{c}\text { GII } \\
\text { (Hypo+Se) }\end{array}$ & $55.7 \pm 1.0 \mathrm{ac}$ & $64.5 \pm 1.3 \mathrm{C} \mathrm{B}$ & $175 \pm 5.1 \mathrm{c}$ & $9.6 \pm 1.0 \mathrm{c}$ & $\begin{array}{l}16.5 \pm 2.0 \\
\mathrm{c}\end{array}$ \\
\hline
\end{tabular}

-Different letters within column mean there is a significant difference at $\mathrm{P} \leq 0.05$. -similar letters with in column mean there is a non-significant difference at $\mathrm{P}>0.05$.

\subsection{Histological Finding:}

Control groups: in this group, the testis exhibited normal architecture . it made up of many rrounded to oval seminiferous tubules (ST) separated by narrow connective tissues interstitial spaces (Fig.1). Each tubule is surrounded by intact basal lamina on which arrest spermatogenic and sertoli cells. The spermatogenic linage consist of spermatogonia that rest on the basement membrane and appeared as small cells with rounded nuclei, followed by large primary spermatocytes with large spherical nuclei. spermatids were detected along with spermatozoa that filled the lumen of ST (Fig. 2). In addition, between the germ cells there was a sertoli cells (supporting cells) which characterized by its oval or triangular nuclei, in the interstitisum there were blood vessels with clump of rounded eosinophilic leydig cells (Fig 3).

Hypothyroid group: experimental hypothyroidism produced histological changes in testicular parenchyma represented by the widening of interstitisum with several ST had irregular boundaries, there were dilated and congested blood vessels in the interstitium (Fig. 4). Some seminiferous tubule showed disorganization of the germinal epithelium with wide gap spaces between the cells associated with exfoliation of the germinal epithelium to lumen of tubule ( Fig. 5) degenerated cells with a dark nucleus and highly eosinophilic cytoplasm were detected associated with vacuoles in the cytoplasm of spermatocye and in the interstitium there was hyaline acidophilic material (Fig. 6). Moreover, some tubules showed regulatory and thickening of their basement membrane with few, vacuolated Sertoli cell and arrested spermatogenesis at spermatocyte level with few leydig cells ( Fig. 7).

\section{Hypothyroid + selenium treated} group: treated rats with selenium showed improvement in the histopathological changes induced by hypothyroidism . Most of ST looked normal with a regular outline and lumen contain sperm, with less widening of intertubular space (Fig. 8). Most of ST showed improvement of the germinal epithelium with spermatogonia spermatocyte, spermatid and spermatozoa, there were few gap spaces between germinal epithelium (Fig. 9). 
Still, there is edema in the interstitium
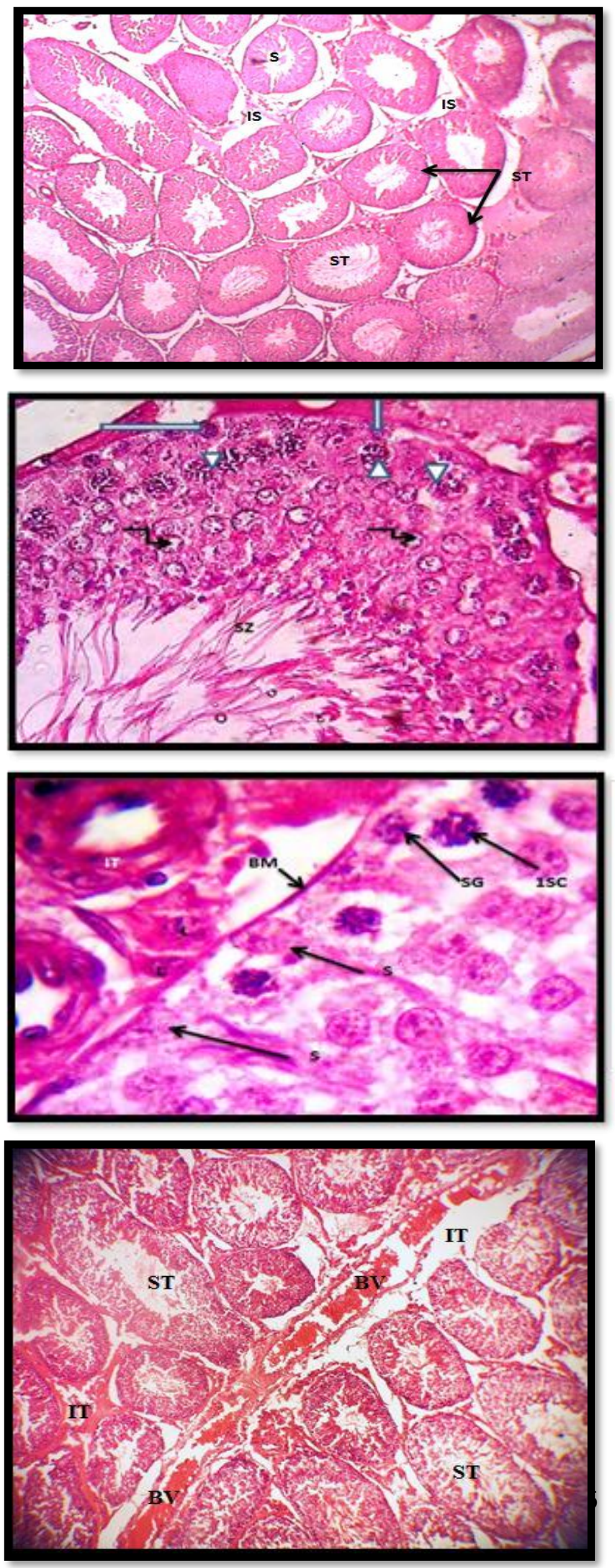

with increased leydig cells (Fig. 10).

Fig .1: Control group, testicular tissue showed many rounded and oval seminiferous tubule (ST). Narrow interstitial tissues (IS). H\&E, 100X

Fig .2: Control group, seminiferous tubule showed basement membrane (BM) spermatogonia (arrow). Primary spermatocyte (head arrow), spermatid (curved arrow), spermatozoa (SZ) filled the lumen of ST. H\&E.400X

Fig3: Control group showed spermatogonia (SG), sertoli cell (S) rest on basement membrane (BM). Primary spermatocyte (1SC). Interstitial tissue (TT) with leydig cell (L) and blood vessel (BV) H\&E. 400X.

Fig.4: Hypothyroid testis. Testicular tissue showed irregularly of some seminiferous tubule (ST) with widening, edema and hemorrhage of interstitial tissue (IT). Dilated blood vessel (BV). H.E.100X. 

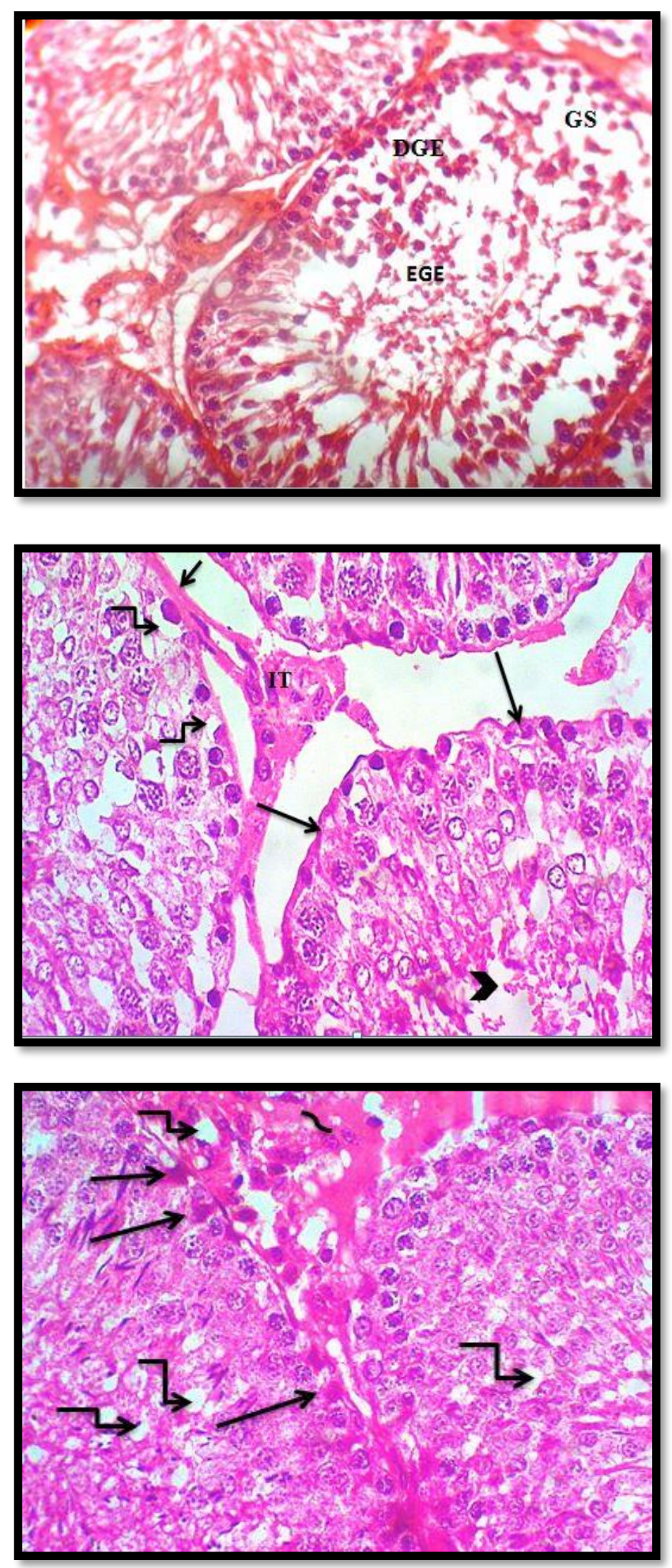

Fig.5: Hypothyroid group: seminiferous tubule showed disorganization of germinal epithelium (DGE) with wide gap spaces between the cells (GS). Exfoliation of germinal epithelium to lumen of tubule (EGE).

Fig.6: Hypothyroid group some ST showed irregularly of basement membrane (arrows). Vacuolated cell (curved arrows). Arrested of spermatogenesis at spermatocyte level with degenerated spermatid (head arrow). Interstitial space (IT) with few leydig cell. H\&E.400X

Fig 7: Hypothyroid Group: seminiferous tubule showed degenerated cells with dark nucleus (arrows). With Vacuoles in the cytoplasm of spermatocye and in the interstitium (curved arrows) associated with deposition of hyaline acidophilic material ( ح). H\&E. 400X 

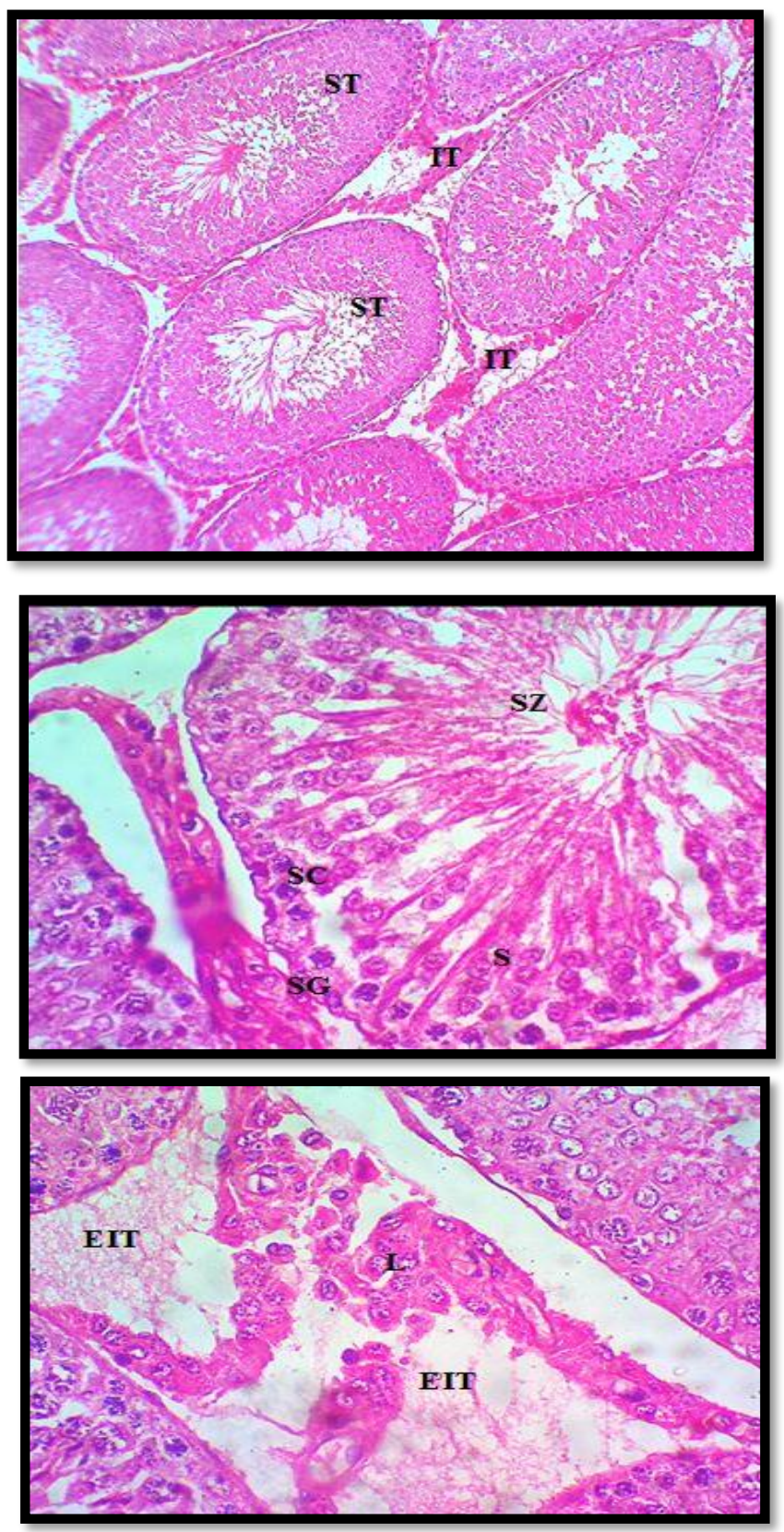

\section{4-DISCUSSION}

Hypothyroidism is a clinical condition caused by reduction in the secretion of thyroid hormones from thyroid gland, it adversely affects the function of many organs including the reproductive function $^{21}$. A previous study confirmed the role of thyroid hormones in testicular development ${ }^{5}$, other one suggested that thyroid dysfunction in adult men was
Fig.8. Hypothyroid- selenium treated group: testicular tissue showing most of seminiferous tubule (ST) look normal with regular outline and lumen contains sperm(S).with less widening of intertubular space. $\mathrm{H} \& \mathrm{E}$.

Fig.9. Hypothyroid- selenium treated group, ST showed improvement of germinal epithelium, spermatogonia SG) speratocyte(SC), spermatid (S) and spermatozoa (SZ). still there were few gap spaces ( GS)between germinal epithelium.H\&E.300X

Fig.10: Hypothyroid-selenium treated group: still there is edema in the interstitium (EIT) with increased leydig cells (L). H\&E $400 \mathrm{X}$

related to an abnormality in sexual activity and impaired fertility ${ }^{22}$.

TSH and T4 were used as an indicator for normal thyroid function in human and other animals ${ }^{23}$. The induction of hypothyroidism in this study was confirmed by significant reduction in $\mathrm{T} 4$ and elevation of $\mathrm{TSH}$ concentration. This result coincide with other studies that used carbimazole for 
six weeks to induce hypothyroidism in experimental animales ${ }^{24}$. The reduction of thyroid hormones level is due to the action of carbimazole which inhibit iodination of tyrosine in the thyroid gland and as a consequences the concentration of TSH was elevated by positive feed-back effect on hypophysis $^{25}$. However, the thyroid function was improved by given selenium to hypothyroid rats in which the level of T4 and TSH were closer to the control group.

The correlation of hypothугоidism to testicular function is controversial some authors showed that hypothyroidism poorly affect testicular function ${ }^{26,22}$

However, The achieved data of this study approved that hypothyroidism produced a structural change on the testis represented by irregularity of the outline of some ST with arrested of spermatogenic maturation and exfoliated of germinal epithelium in the lumen of tubule. Moreover, there was disorganization in germinal epithelium with decreased in the height of these cells. Reduction in the number of spermatocytes, spermatid, sertoli and leydig cells had been recorded. A similar finding was obtained by other authers ${ }^{24}$, 27. To understand the structural changes of testicular tissues produced by hypothyroidism, the oxidant-antioxidant state was studied in this work by measuring the level of MDA which is regarded as a marker for oxidative stress. The obtained data showed a significant elevation of MDA level in the hypothyroid group. This result was in accordance with other researchers who attributed the pathological features of testis in hypothyroidism to the accumulation of free radicals and increased oxidative stress with lipid peroxidation which was responsible for cellular damage and testicular dysfunction that represented by a reduction in sperm count with an increase of abnormal and immotile sperm $^{28}$.

Furthermore, the reduction of testosterone level which observed in this study and also reported by other investigator $^{29}$ may explain early detachment of spermatids from Sertoli cells leading to exfoliation of degenerated cells in the lumen of the ST.

The reduction of testosterone level in hypothyroidism may be attributed to many factors as decreased production of binding globulin for sex hormones from the liver ${ }^{30}$. Other factors include the disruptor effect of hypothyroidism on hypothalamus-pituitary-testis axis with the subsequent reduction in testosterone ${ }^{31}$. While other authors explain the inhibition of steroidogenesis to the effect of hypothyroidism on the number and function of leydig cells ${ }^{32}$

Moreover, The result of current study showed widening of interstitisum associated with edema and dilated blood vessels. This result was observed by another investgator ${ }^{24}$. This may be related to an excess of lymphatic exudate and capillary destruction which result from increased blood endotoxins and toxic effect of free radicle in oxidative stress status ${ }^{32}$. The treatment of hypothyroid rats in the current study with (Se) showed improvement in the thyroid function represented by elevation of T4 with depression of TSH level compared to hypothyroid group ( GII) and this result was supported by other studied 33,34 who explained this improvement by the action of Selenoenzyme, which has an important 
role in thyroid hormones production. Moreover, treatment of rats with (Se) resulted in a significant increase in testosterone level and improvement in structural changes induced by hypothyroid status. This result was in agreement with another study that observed an improvement in the ultrastructure of rat's testis treated with carbimazole ${ }^{35}$. Many investigators studied the effect of (Se) on toxicity produced by different chemicals, however, some reported it's protective effects $^{36}$. While others deny $i^{37}$. Santos

\section{Acknowledgments}

Authors extend grateful thanks to the Faculty of Veterinary Medicine Mosul, Iraq for their help during research work.

\section{5- References}

1. Guyton A and Hall J. Guyton and Hall Textbook of Medical Physiology. 12th ed ., Saunders; Elsevier Limited, USA, (2011): P.907

2. Alahmar A, Dutta S, Sengupta P. Thyroid hormones in male reproduction and infertility. Asian Pac J Reprod 2019; 8(5): 203-210.

3. Wajner SM, Wagner MS, Melo RC, Parreira GG, Chiarini-Garcia H, Bianco AC. Type 2 iodothyronine deiodinase is highly expressed in germ cells of adult rat testis. J Endocrinol, 2007;194: 47-54. 4. Billings, H.J, Viguie, C, Karsch, F.J.; Goodman, R.L, Connors, J.M. and Anderson, G.M .Temporal requirements of thyroid hormones for seasonal changes in LH secretion. Endocrinol . 2002; 143(7): 2618- 25.

5. Carani, C, A. M. Isidori, A. Granata, E. Carosa, M. Maggi, A. Lenzi,. Multicenter study on the prevalence of and Takahashi (2008) reported that chemo protective mechanism of (Se) may be due to it's antioxidant activity as well as it' s role in the reduction of lipid peroxidation and in DNA repair pathway $^{38}$.

In conclusion, the current study noted the protective effect of selenium against structural changes of rat testis induced by hypothyroidism. This may be attributed to its role in thyroid hormones production as well as its an antioxidant activity with reduction of oxidative stress induced by hypothyroidism

\section{Conflict of interest}

The authors assert no conflict of interests of the manuscript.

sexual symptoms in male hypo- and hyperthyroid patients.- J. Clin. Endocrinol. Metab.2005; 90(12): 647279.

6. Holsberger, D. R, P. S. Cooke. Understanding the role of thyroid hormone in Sertoli cell development: a mechanistic hypothesis. Cell Tissue Res. 2005; 1: 133-140.

7. Tananakina, N., V. I. Kravchenko, I. A. Luzanchuk, I. P. Lubyanova, A. N. Karakashyan, I. V. Kalachova. The frequency of goiter and iodine supply in the southeast region of Ukraine in the beginning of governmental program of iodine insufficiency prevention.Mezhdunar. endokrinol. Zh. 2005; 1: 348 (in Ukrainian).

8. Fatourechi V. Subclinical hypothyroidism: an update for primary care physicians. Mayo Clinic Proceedings.2009;84:65-71.

9. Krassas, G. E., K. Poppe, D. Glinoer.. Thyroid function and human 
reproductive health.- Endocr. Rev. 2010; 31 (5): 702-55.

10. Krassas G.E.,and Pontikides N Male reproductive function in relation with thyroid alterations. Clin Endocrinol Metab. 2004; 18:183-95.

11. Krassas G. E., Pontikides N., Deligianni V., Miras K. A prospective controlled study of the impact of hyperthyroidism on reproductive function in males. J Clin Endocrinol Metab. 2002;87:3667-71.

12. Sahoo DK, Roy A, Bhanja S, Chainy GB. Hypothyroidism impairs antioxidant defense system and testicular physiology during development and maturation. General and Comparative Endocrinol. 2008;156: 63-70.

13. Zamoner A, Barreto KP, Filho DW, Sell F, Woehl VM . Propylthiouracilinduced congenital hypothyroidism upregulates vimentin phosphor ylation and depletes antioxidant defenses in immature rat testis. J. Mol. Endocrinol. 2008;40(3) :130-4.

14. Kücükakin B, Gögenur I, Reiter RJ, Rosenberg J. Oxidative stress in relation to surgery: is there a role for the antioxidant melatonin? J Surg Res.2009;152: 338-47.

15. El -Demerdash FM and Nasr HM. Antioxidant effect of selenium on lipid peroxidation, hyperlipidemia and biochemical parameters in rats exposed to diazinon. $\mathrm{J}$ Trace Elem Med Biol.2014; 28:89-93..

16. Tinggi U. Selenium: Its role as an antioxidant in human health. Environ Health Prev Med. 2008;13:102-8.

17. Brigelius-Flohé R, Banning $\mathrm{A}$ and Schnurr K. Selenium-dependent enzymes in endothelial cell function. Antioxid Redox Signal. 2003; 5:205-15. 18. Liao Y, Lu X, Lu C, Li G, Jin Y, Tang $H$. Selection of agents for prevention of cisplatin-induced hepatotoxicity.

Pharmacol.

Res.2008;57(2): 125-31.

19. Treesh SA and Khair NS. Effect of thyroid disorders on the adult female albino rats (Histological and Histochemical Study) J Cytol Histol .2014; 5:4.

20. Swathy $S$, Panicker S, Indira $M$. Effect of exogenous selenium on the testicular toxicity induced by ethanol in rats. Ind. J. Physiol. Pharmacol. 2006; 50(3): 215-24.

21. Krassas GE, Markou KB. The impact of thyroid diseases starting from birth on reproductive function. Hormones. 2019:1-7.

22. La Vignera S, Vita R. Thyroid dysfunction and semen quality. Int $\mathbf{J}$ Immunopathol Pharmacol 2018; 32: 1-5. 23. Kelly, G.S. Peripheral metabolism of thyroid hormones: a review, Altern Med Rev. 2000; 5:306- 33.

24. Saber Abdel-Rahman Sakr, Sobhy Elsaid Hassab ELnaby, Yosry Aly Okdah, Ahmed Mohamed El-Shabka. Impact of ginger aqueous extract on carbimazole induced testicular degenerative alterations and oxidative stress in albino rats. J Coast Life Med . 2017; 5(4): 167-173.

25. Abraham P, Avenell A, Park CM, Watson WA, Bevan JS. A systemic review of drug therapy for Graves hyperthyroidism. Eur J Endocrinol. 2005;153:484-98

26. Wagner MS, Wajner SM, Mala AL. Is there a role for thyroid hormone on spermatogenesis? Microsc Res Tech. 2009; 72: 796-808.

27. Prathima P, Venkaiah K, Pavani R, Daveedu T, Munikumar M, Gobinath M, Valli M, Sainath SB. $\alpha$-lipoic acid inhibits oxidative stress in testis and attenuates testicular toxicity in rats exposed to carbimazole during 
embryonic period. Toxicology reports. 2017;4:373-81.

28. Hoda I. Bahr and Abdelaziz E. Ibrahim. Phytopreventive effect of Salvia officinalis L. on infertiliy induced by hypothyroidism in male albino rats. Int. J. Sci. Res. 2015; : 4 (1) :2277 -79

29. Donnelly P., White C. Testicular dysfunction in men with primary hypothyroidism; eversal of hypogonadotropic hypogonadism with replacement thyroxine. Clin Endocrinol.2000; 52: 197-201.

30. Jassim. M. A. Alkal and Sarah. J. S. Alzerjawi. Effect of propyl thiouracilinduced hypothyroidism on reproductive effeciency of adult male rats. Bas.j.vet.Res. 2013; 12(2): 113-21

31. Chiao Y.C., Cho W.L., and Wang P.S. Inhibition of testosterone production by propylthiouracil in rat Leydig cells. Biol Reprod 2002;67:416-22.

32. Jalilvand N, Hosseini M, Beheshti F, Ebrahimzadeh-Bideskan A. Protective effect of PPAR $\gamma$ agonist pioglitazone, on testicular tissue and sperm parameters in hypothyroid rats. Toxin Reviews. 2019;24:1-10

33. Amara, I.B.; Bouaziz, H.; Guermazi, F. and Zeghal, N. Effect of selenium on 38.Santos R A, Takahashi C S Anticlastogenic and antigenotoxic effects of selenomethionine on hypothyroidism induced by methimazole (MMI) in lactating rats and their pups, Acta Biologica Hungarica. 2010; 61(2), pp: 145-57.

34. Erdal, M.; Sahin, M., Hasimi, A.; Uckaya, G.; Kutlu, M. and Saglam, K. Trace element levels in hashimoto thyroiditis patients with subclinical hypothyroidism", Biological Trace Element Research.2008;123(1-3):1-7. 35. Saber A. Sakr, Hoda A, Mahran Amany E. Effect of selenium on carbimazole-induced ultrastructural changes in testes of albino rats. Egypt. J. Exp. Biol (Zool.) . 2011; 7(1): $33-41$ 36. Kara H, Cevik A, Konar V, Dayangac A, Yilmaz M. Protective effects of antioxidants against cadmiuminduced oxidative damage in rat testes. Biol. Trace Elem. Res. 2007; 120(1-3): 205-11.

37. Adesiyan AC, Oyejola TO, Abarikwu SO, Oyeyemi MO, Farombi EO. Selenium provides protection to the liver but not the reproductive organs in an atrazine-model of experimental toxicity. Exp. Toxicol. Pathol. 2011; 63(3): 201-7. 